\title{
Factors Affecting the performance of Small-Scale Enterprise (Restaurant and Hotels) Inraya Azebo Wereda: The Case of Mohoni, Maychew and Korem
}

\author{
Meseret Meresa* \\ Faculty of Business and Economics, Department of Management, Adigrat University, Ethiopia \\ *Corresponding Author: Meseret Meresa, Faculty of Business and Economics, Department of \\ Management, Adigrat University, Ethiopia
}

\begin{abstract}
This study focused on the assessment factors affecting of small-scale enterprise the case of restaurants and hotels business in the raya Azebo Wereda southern Tigray. The objective of the study was to investigate the factors affecting of small-scale enterprise (restaurant and hotels) in raya Azebo Wereda: the case of mohoni, maychew and Korem.

The accessible population was the three hundred and eleven (311) registered and 181 selects from the registered restaurant and hotels business in raya Azebo Wereda but returned 169. The study used stratified random sampling to group the businesses into homogeneous entities. This study to select the number of sample respondents proportionally from each stratum then drawn from the each group. Questionnaires with both open and closed items used to obtain data. Statistical Package for Social Sciences (SPSS) version 20 was used to analysis of quantitative data obtained from questionnaire questions.
\end{abstract}

The study finding that had revealed that restaurant and hotels operating in the study area have been confronting with a number of problems. Among those factors affecting are the major ones include poor infrastructural facilities (like electricity and water), high rank level of competition, lack of access to finance, lack of knowledge and skill. In addition to this lack of access to market, lack of necessary support from relevant institutions specially to MSE's office, shortage of raw materials, managerial and technical skills, lack of additional facilities and enough space to accommodate the fluctuations in customers' arrival.

The Recommendations to the factors affecting of restaurant and hotels business are encouraging service providers of the enterprises had better convince and aid such enterprises to prepare business plan. In addition, Provision of training on quality improvement and finally organized the office of MSE's prepare the regularly entrepreneurship training program especially to the new business, produce quality product, give training how to customer handling to the owners.

Keywords: SSE's, Factors Affecting, Raya Azebo Wereda, South Tigray.

\section{INTRODUCTION}

\subsection{Back Ground of the Study}

Micro and Small businesses exist in almost every industry. They can range from mom-and-pop convenience stores to small manufacturing plants. Additional types of small-scale enterprises can include privately owned restaurants, law firms, inns, bakeries, architectural and engineering firms, dry cleaners, coffee house and construction contractors. Such enterprises are generally privately own and operated sole proprietorships, corporations or partnerships. The legal definition of a micro and smallscale enterprise varies by industry and country.

The fundamental contribution of the small business sector to the overall performance of the economy is indeed a crucial motive for researchers to investigate and examine the key success factors behind this sector. Small businesses face many challenges that hinder their growth or even further cause a permanent shutdown. Most micro and small businesses are control by their owners because they could not have fund for to hire proficiency to run the businesses for them (Raja ram, 2008). The independent and private ownership (sole proprietorship or partnership) of small business always endorse uncertainty (Keasey and Watson, 1993). 
Small business success or failure directly depends on the sole ability of the owner(s) without defend of limited liability; the owners of small business may be personally liable for the business misfortunes such as debts (Carter and Jones-Evans, 2006).

According to Akande (2006), small businesses heavily rely on owner's skills, ability, and personal characteristics for the success of the business. However, small business, across the industrial world, still account for a significant fraction of developed build up.They play some defined roles in the economy that support and strengthen the growth of a nation (Mwobobia, 2012).

Small business in Ethiopia is no exception in this regard facing the mentioned challenges as reveled by researches conducted in various parts of the country. For instance, a study made by (Garoma, 2012: 177; Habte, 2012: 66) on the micro enterprise of Addis Ababa in the urban informal sector confirmed such pointed factors as the determinants of the enterprise success.

According to Werotew (2010: 226-237) also that 'environmental factors such as social, economic, political, and legal along with, internal (personal) factors like individual attitudes, training and technical know-how are all the constraints that are challenging the success of Ethiopians small business enterprise.

The current small business environment in Ethiopia is relatively inviting and more stable when compared with the past regime. The government has formulated different policies that encourage entrepreneurs to take the initiative to start venture of their own. Among the different kinds of entrepreneur in Ethiopia, these are engaged in the restaurant and hotels businesses are significance. This businesses industry plays a curtail role in the overall economy of Ethiopian by creating job opportunities for a considerable number of people.

\subsection{The Statement of the Problem}

The key role of micro and small business enterprises to the building of indigenous based and growth national economies and advancing technological innovations has created the situation that small businesses collectively have a greater stake in promoting corporate citizenship in general (Taylor, 2004).

Increase of transportation costs and increase cost of make operation of micro and small businesses difficult (Opara, 2011). Bad infrastructure network has been a problem for the small business owners. In addition to the Bad infrastructure network is Consumers find it difficult to reach certain places and will prefer to buy their goods that are available along the road rather than an area reserved for small business owners, but with inaccessible roads.

According to Arinaitwe (2006), small business enterprises are countenance with the problems of lack of expertise, lack of managerial skills, inadequate legislature to protect small business enterprise against the competitions from multinational and imported goods and limited of finance. The financial institution policies Credit in Nigeria have also a propensity to discriminate against small-scale enterprises; as a result, most of these enterprises have been force to obtain funds from family members and from micro credit markets, which interest rates are very high and often injurious.

According to Carter \& Jones-Evans (2006) also clearly put the followings as the strategic problems of micro and small business enterprises- un availability financial resources, marketing problems and customer concentration, poor management skills, lack controls, and technology skills. They further explained that most small business are undercapitalized and are improperly capitalize in terms of both a high debt-equity ratio. Small business managers fit into place in little marketing activity and have no awareness of marketing, prefer to apply their time to activities that products that are more familiar.

According Parsa, H. (2007) the factors that contribute to restaurant challenges can be divide in to two major types. The first type macro factor that contribute to restaurant failure are economy, legislation, climate and natural event, regional and urban planning, changing cultural factor and new competition. The other second type micro factor that contribute are capital, location, quality of life, entrepreneurial incompetency, experience, leadership, ability to create, name of restaurant, design and layout and high fixed cost.

Many factors challenge the performance of restaurants and coffee house businesses either positively or negatively. Which in turn will determine their fate in the competitive business environment? These 
factors, which contributes to the success of the enterprises, are categorized as internal attributers (personal and business related) and external attributers (governmental, access to market, infrastructure) factors (Beyene, $2007: 39$ ).

Furthermore, previous studies conducted in Ethiopia focused on the regional level, sub cities of Addis Ababa - Ethiopia and zonal level. So that, this work contribute to fill show the knowledge gap instead of restaurant and hotels existed at Wereda level and what major factors mostly affecting at the small scale business level with the references' of restaurant and hotels. In glow of the above-mentioned fact, it is very important to investigate the Factors affecting of small-scale enterprise the case of restaurants and hotels business in the raya Azebo Wereda southern Tigray. And in dealing this study attempt to answer the important question of why in this Wereda restaurant and hotels begin every year but the business are be unsuccessful their operation while shut down before their six month or one year. Thus, means cause of short live of the small business is the study area (since the data shows in the Wereda increases closed the restaurant and hotels year to year)

This study will investigate the Factors affecting of small-scale enterprise the case of restaurants and hotels business in the raya Azebo Wereda southern Tigray raising the following research questions:

\subsection{Research Question}

- What are the internal factors affecting of restaurant and hotels in the study area?

- What are the Eternal factors affecting of restaurant and hotels in the study area?

\subsection{Objectives of the Study}

\subsubsection{General Objective of the Study}

The overall general purpose of this study was to identify the Factors affecting of small-scale enterprise (restaurants and hotels) in raya Azebo Wereda: the case of Mohoni, Maychew and Korem.

\subsubsection{Specific Objective of the Study}

Based on the above general Objective the following Specific objectives formulated.

- To investigate the internal factors affecting of restaurant and hotels in the study area.

- To examine the eternal factors affecting of restaurant and hotels in the study area.

\subsection{Scope of the Study}

In order to address the research objectives, the study enclosed spatially and operationally. The study is limited to Tigray Regional state, Raya Azebo Wereda in three areas (mohoni, maychew, and Korem) to overcome the existing problem regarding Factors affecting of small-scale enterprise the case of restaurants and hotels business.

It also delimited to those SSE's engaged in restaurant and hotels business that been registered under the SSE's development strategy of Ethiopian government and licensed by each centers of SSE's service center in the sub Town. This study delimited to those small-scale enterprise businesses, which are engaged in restaurant, and hotels businesses only.

\subsection{Limitation of the Study}

Sufficient documents concerning the subject under study were lacking. Time constraint has prevented proper and thorough review of empirical and theoretical data that related to the study. Lack of relevant data and biased judgment of interviewees were some of the other problems, which encountered.

To begin with, the fact that the majority of the respondents' educational background is low creates some negligence in filling the questionnaire. Some do not give values to the questionnaire and some others do not return it totally. Furthermore, since the respondents were scattered in different town, some difficulties faced in giving orientations, following up respondents and collecting responses. Therefore, these conditions might affect the quality of the paper to some extents.

Lack of research conducted by other research on this topic in the study area context in which this study is undertake, which may help the researcher as reference, is limitation of this study. 
The study covers only the factors affecting of the firm under study in small business level. The other micro extraneous, which impinges the business, is not cover due to the vast area of such study. The result of the study in concerned with restaurant and hotels factors affecting in Raya Azebo Wereda Tigray region only. Hence, it cannot be generalize

\subsection{Significance of the Study}

This study intended to provide the following significances:

Understanding the factors affecting of restaurant and hotels businesses can enable the management, solve the problem and the owners of small-scale enterprise business may improve their performance in order to reach their business objectives.

The research opens the door for more empirical studies regarding restaurant and hotels businesses. It will also provide an insight that serve as a reference for other researchers who intend on undertaking an in-depth study on this area or other related areas.

Though there are many studies conducted in small scale business firm there no study which is specific regarding restaurant and hotels business in Raya Azebo Wereda hence, the study focuses on the business firms which one specifically operating in restaurant and hotels businesses.

\subsection{Organization of the Study}

The research report consisted five major chapters. The first chapter is an introductory chapter, which consists of Background of the study, Statement of the problem, Objectives of the study, Significance of the study, Scope of the study, Limitation of the study, and Organization of the paper. The second chapter reviews literature that related to the study. The third chapter incorporates the methodology of the study, which deals about what methods, and materials are used. The analysis, presentation and summary of the data collected from respondents constitutes the forth chapter. The last chapter incorporates conclusion and recommendation. Other supplementary part of the research report isgive before and after these five chapters.

\section{REVIEW OF RELATED LITERATURE}

\subsection{Definition of Small-scale Enterprises}

Worldwide, there is no common definition of the SSE's. Although the Size criteria (number of employees, sales turnover, Asset size total capital investment and the like), and Economic criteria (market share, independence and personalized management) are the two main approaches used to define SSEs (Beyene, 2007: 39). This shows the definition of SSE's Vary from country to country depending largely on the size of the economy, the levels of development, culture and population size of a country involved.

In the case of Ethiopia, until recent times there is lack of uniform definition at the national level to have a common Understanding of the MSE sector. While the definition by Ministry of Trade and Industry (MTI) uses capital investment, the Central Statistical Agency (CSA) uses employment and favors capital-intensive technologies as a yardstick. Recognizing that there are no standard definitions of MSE's, that their definitions vary from country to country a working definition for the purposes of this paper one given by the federal micro, and small enterprises development agency, which considers the inflation and fluctuations/irregularity of currency for the coming 5 years, is as below.

\subsection{Small Enterprise}

\subsubsection{Industrial Sectors (manufacturing, construction and mining):}

It operates with 6-30 persons and/or with a paid up capital of total asset Birr between 100,000(one hundred thousand) and not exceeding Birr $1.5 \mathrm{~m}$.

\subsubsection{Service Sector (retailer, transport, hotel and Tourism, ICT and maintenance service)}

It operates with 6-30 persons or/and total asset, or a paid up capital is with Birr between 50,001 and not exceeding Birr 500,000(FeMSEDA, 2011: 13).

The importance of the micro and small enterprises sector in Ethiopia, particularly for the low income, poor and women groups, is evident from their relatively large presence, share in employment and 
small capital requirement. These are sufficient reason for governments and other stakeholders in development to be interested in micro and small enterprises. However, in the context of many developing countries, countries in transition in particular including Ethiopia, MSEs also seen as an emerging private sector, forming the basis for private sector led growth. In Ethiopia, at the level of strategy and policy, these roles of MSEs have received recognition. They see as means of providing employment, alleviating poverty, ensuring food security, and private sector development (Gebrehiwot and Wolday, 2006).

\subsection{Characteristics of MSEs}

Zewde(2002) identified that the MSE sector characterized by a number of highly diversified activities, which can create job opportunity for a large segment of the population. The characteristics of the informal sector (small and micro enterprises) have also been describeas it is easy to enter, it is financed mainly from personal and family resources, it requires low starting capital, it uses laborintensive techniques, and it relies on the non-formal school system such as apprenticeship and on-thejob training.

Liedholm, et.1 (1999) also identified the following distinguishing features, namely more labor intensive, more efficient, more equitable in distributing the income they generated, geographically more widely diversified, and more nurturing of entrepreneurs.

\subsection{The Role of Small Enterprises in Poverty Alleviation}

By now, it is clear and agreeable that poverty, both in urban or rural areas, is all about lack of basic needs, health care, clean water, sanitation, education and low or inadequate level of income and consumption, and poor command over resources. Before reaching in to such multifaceted understanding of the concept of poverty, poverty was viewed in terms of level of income in the late 1950 's and 60's. Then onwards, however, the trend of defining it begun to incorporate other noneconomic aspects. Likewise, on the other hand, according to Green et al (2006), one important innovation, since the late 1980's and early 1990's, in development research and policy has been the refocusing of the goals of development strategy from an exclusive concern with economic growth to 'growth with poverty reduction' through MSE's development. Again during these decades, the roleplay by MSE's, through the various socio-economic benefits emanating from the sector, was found to be eminent in the overall development effort and process of nations. In other words, by generating larger volumes of employment as well as higher levels of income, the SMEs will not only have contributed towards poverty reduction, but they will also have enhanced the welfare and standard of living of the many in the society (Mukras, 2003 cited in Mulugeta, 2011).

As shown above, central to the problem of poverty is the availability of work. Work, secured as either owner or employee in MSE's, allows people to produce for themselves (i.e. food) and earn the money needed to buy goods and services. In this point poverty, reduction can be correlate with job creation. According to Vandenberg (2006), it is also from work that wealth created which, through taxation, allows governments to fund pro-poor services such as health care, clean water and education. Hussmans and Meharan (2005), indicated that small-scale enterprise can spark of socio-economic revival as they need little capital to operate but can contribute much for they work with minimum simple and inexpensive equipment's and management skills. They can be adapted quickly and create quick self-employment and jobs much needed by the enumerable job seekers.

The health of micro and small business sectors enhance the overall economy of the country, since they utilize local resources, satisfying vital needs of large segment of the population with their products and services, serve as spheres of technological, marketing and management capacity and skill acquisition, and enable technological progress via adoption technologies (FeMSEDA, 2004).

The value of the small business sector is recognize in economies worldwide, irrespective of the economy's developmental stage. The contribution towards growth, job creation and social progress is valued highly and small business regarded as an essential element in a successful formula for achieving economic growth.

Small-scale enterprises are one of the priority areas of action among the Programs addressing African development (UN, 2008). It could see as a means of achieving smooth transition from tradition to 
modern industrial sector; and has a huge contribution to the growth and development of the country in terms of employment generation with a relative low capital cost (Stephen \& Wasiu, 2013).

\subsection{Theoretical frame work}

The concept of SSEs has been define and use differently in different countries. This reveals the absence of one universally accepted definition of SSE's. In most cases, SSE's are define based on the number of people employed in the enterprises, investment outlay, and annual sales turnover, paid up capital or a combination of these measures (Stephen \& Wasiu, 2013).

SSEs show that the promotion of SSEs is one of the policy strategies forachieving national development goals such as poverty alleviation, economic growth increasingPeople's participation in economic activities, employment creation and income generation(Raymond, 2009). People, especially in the developing parts of the world, establish and runSSEs mainly to earn income and consequently bear up poverty, which can be explained in bothincome and non-income, based aspects. Although people is ultimate goal in undertaking anylivelihood activity is to escape poverty by enhancing their status of wellbeing (Rigg, 2007).

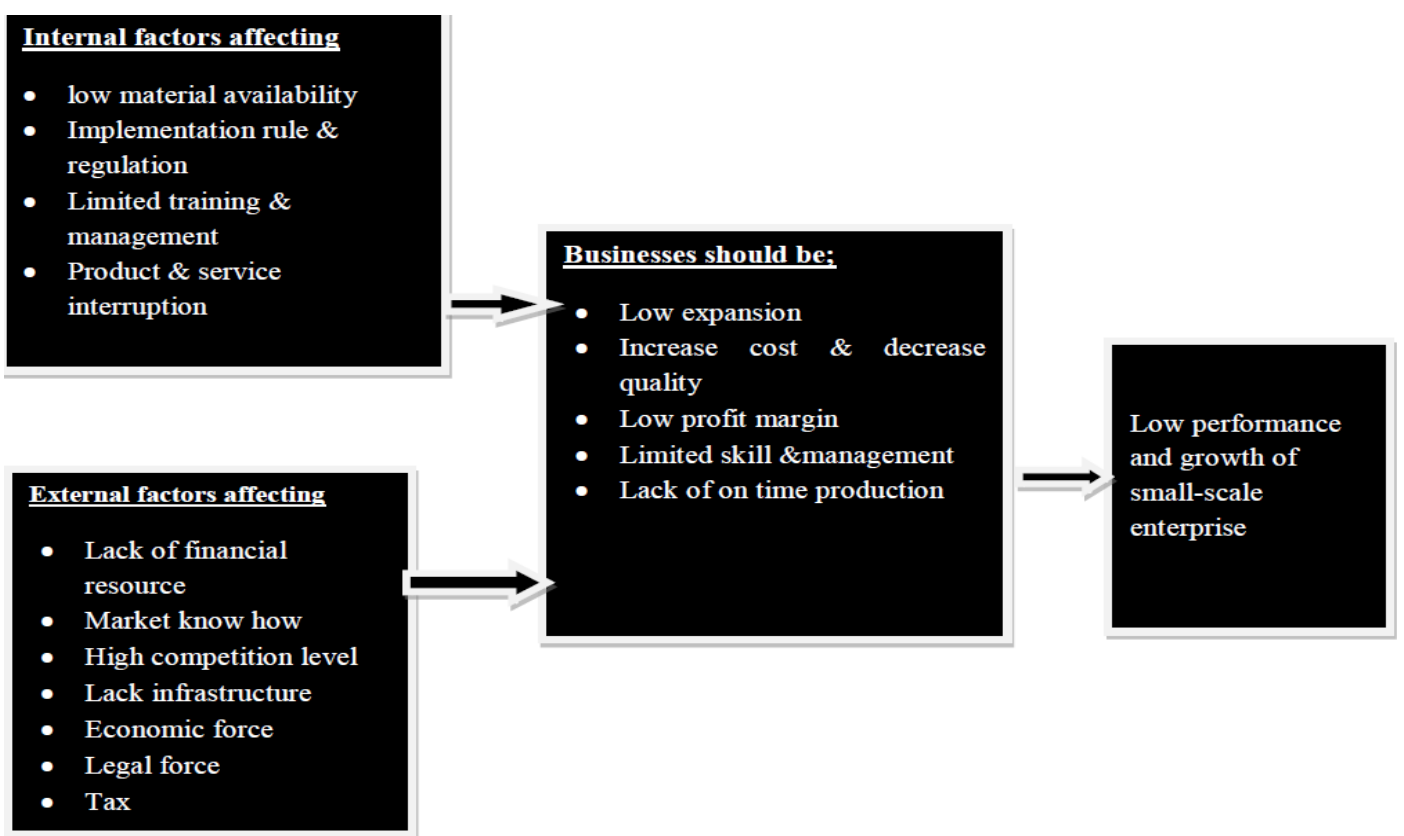

Figure1. Factors affecting of SSE's

Source: Adopted from Weldegebriel, M. (2012)

\subsection{Empirical Review of Mses in Ethiopian}

In Ethiopia, the MSE sector has high capacity in absorbing high labor force; this is because the sector characterized by diversified activities. Due to its contribution for alleviating the poverty of the lowincome people and of course with a number of constraints micro and small enterprises, get the attention of many researchers.

Accordingly, Daniel (2007) with having an objective to assess the impact of group-based MSEs on poverty alleviation conducted a research in Nekemte city of the Oromia Regional State of Ethiopia. According to this study, $48 \%$ of the surveyed respondents are of a view that their income has increased while $22.7 \%$ said that their income has decreased because of their engagement in the studied MSE's. The study further indicated that the studied respondents consumption expenditure has increased after they start to work in MSEs, which has resulted in the improvement of the operators consumption and ownership of water, housing, household assets, education and medication. The same study showed that MSEs have a protective role on averting vulnerability of their members to risks such as food shortage, unemployment and lack of income. Most importantly, the research pointed that MSE's have helped for the economic empowerment of women. Lastly, the study identified that Lack of market, stiff competition, lack of working capital, raw material shortage and poor managerial skills are among the problems that MSEs are encountering. 
Ephraim (2010) indicated that MSEs are contributing a lot for poverty alleviation but they are facing multi-dimensional problems both at start up and operational levels. Considering the main problems of the enterprises in different sectors, this researcher reveals that, startup capital; high interest rates, skilled personnel, production place, unaffordable tax and /or rent, in adequate support from Government/NGO, lack of credit facilities, and lack of access for training were among the major impediments for operator/manager at the grass root level of SSEs activities. This study also revealed that, the severity of MSE's problem varies depending on the type of sector. I.e. Problems in one sector are different from the other.

Getahun (2009) carried out a research in Gullele sub-city of Addis Ababa city to assess the impact of MSE intervention on urban poverty reduction by examining the level of employment creation, change in income and living standard of the beneficiaries in terms of education, health, household assets and clothing. The study found out that the studied MSE's have created a permanent and temporary employment opportunity. The income and expenditure of the beneficiaries of the MSE's program has shown an increment, according to the study. The respondents believed that their engagement in the MSE's has resulted in an improved health and clothing, and increased ownership of basic household assets such as table, chair, bed, radio and tape recorder.

Forinstance, Workneh's (2007) research undertaken in Kolfe Keraneo sub-city of Addis Ababa indicated that lack of capital, lack of market, unfavorable policy, and inadequate infrastructure, absence of adequate and relevant training, bureaucratic structure and procedures are among constraints faced by MSE's. The researcher suggested a sustainable and non-politicized support to the studied MSEs i.e. block manufacturer enterprises.

Similarly, Adil's (2007) research carried out in Addis Ababa's two sub-cities' industrial zones showed that inappropriate government intervention, shortage of capital ,location disadvantage, lack of market and lack of display room are the major challenges that obstruct MSE's.

Mulugeta (2011) in his study entitled the livelihoods reality of small enterprise operators identified and categorized the critical problems of the MSE's in to market-related problems, which are cause by poor market linkage. And also poor promotional efforts; institution related problems including bureaucratic bottlenecks, weak institutional capacity, lack of awareness, failure to abide policies, regulations, rules, directives, absence of training to executives, and poor monitoring and follow-up; operator-related shortcomings like developing a dependency tradition, extravagant and wasting behavior. In addition to this lack of vision and commitment from the side of the operators; MSErelated challenges including lack of selling place, weak accounting and record keeping, lack of experience sharing, and lack of cooperation within and among the MSEs; and finally society-related problems such as its distorted attitude about the operators themselves and their products.

Eshetu and Zeleke (2008) conducted a longitudinal study to assess the impact of influential factors that affect the long-term survival and viability of small 25 enterprises by using a random sample of 500 MSMEs from 5 major cities in Ethiopia.

According to the study of Mulugeta (2011), the critical problems of SSEs has recognized and classified in to market-related problems, which are caused by poor market linkage and poor promotional efforts; institution-related problems including bureaucratic bottlenecks, weak institutional capacity, lack of awareness, failure to abide policies, regulations, rules, directives, absence of training to executives. Also poor monitoring and follow-up; operator-related shortcomings like developing a dependency tradition, extravagant and wasting behavior, and lack of vision and commitment from the side of the operators; MSE-related challenges including lack of selling place, weak accounting. In addition to this record keeping, lack of experience sharing, and lack of cooperation within and among the MSEs and finally society-related problems such as its distorted attitude about the operators themselves and their products.

Micro and small enterprises have massive contributions in reducing Poverty, creating employment opportunities, increasing income of individuals or improve standard of living of citizens especially in urban area and on the contrary many challenges have come across with the sector.

\subsection{Rationale for Emphasizing Small Scale Enterprise in Industrial Development}

Fabayo (1989) observed that one major claim for focus on SSE's is that they are large employers of labor and this makes them vital in coping with the problems of unemployment and poverty. 
According to him, strong evidences based on country and regional experiences exist to show that small firms are major source of employment opportunities for a wide cross-section of the workforce: the young, old part-time workers and the cyclically unemployed.

Uzor (2004) opined that small scale enterprises (SSEs) contribute to national development by positively influencing the distribution of income in both functional terms, wages and profits in nominal terms. Focus on SSEs help to decentralize industries thereby not only accelerating rural development but also stemming urban immigration and the consequent problems of congestion in the cities. Another rationale for focus on small-scale enterprises (SSE's) is its contribution to value added in the manufacturing sector and to the Gross Domestic Product (GDP) of the economy.

\subsection{Factors Affecting of Small Scale Enterprises}

African entrepreneurs face some unique challenges that hamper their ability to survive and grow, and Ethiopian start-ups are no different. The political, economic and bureaucratic landscapes in which most African entrepreneurs operate are generally similar even though there are unique challenges and opportunities prevailing in each nation, which must be take into account in formulating effective policies to promote entrepreneurship. The public service jobs, engaging in a business venture have not historically been consider a high status profession in Africa although entrepreneurs may become wellrespected citizens when they get rich. This has also been true in Ethiopia (Mersha, Sriram, and Hailu, 2010).

There are various challenges facing micro and small-scale enterprises; while some are financial, others are non-financial. The financial constraints include those factors that prevent small-scale enterprises from accessing funds easily, inadequate sources and supply of funds has been a major setback to the realization of many brilliant business ideas and outward expansion of existing business. An industrial analysis recently observed that one of the reasons why small scale enterprises funds has not been invested, is the operator prefer to get the funds as loan, rather than as equity contribution. To gain access to finance, small-scale enterprises owner should learn to put up realistic business plan supported with financial projections, which highlight the profitability of the enterprises before they seek for funds.

Even though SSE's have important roles in economic development, poverty alleviation, employment opportunity, they are critically challenged by certain impeding factors to sustain within the sector. The research conducted by Bowen, Morara and Mureithi (2009) in Kenya revealed that three out of five micro and small businesses failed within the first few months of operation due to competition, managerial inefficiency, insecurity, debt collection, lack of working capital, power interruptions, political uncertainty, cost of materials and low demand of the products.

The problem confronting SSE's appears to be similar in least developed or developing countries. However, the extent of the problems varies from country to country and industry to industry; and it depends on firms' characteristics (Aremu \& Adeyemi, 2011). Currently, there are many internal and external factors face SSE's in their operations and hinder their growth in Ethiopia (MUDC, 2013). A hard look at various studies has revealed a number of deterrents to the growth and survival of the SSE's. These are summarizing as under.

\subsubsection{Lack of Adequate Finance}

Financial constraints such as inadequate investment capital, insufficient loan, and inefficient financial market are the major obstacles in doing business, and most MSE's are highly risky ventures involving excessive administrative costs and lack of experience in dealing with financial institutions (CLEP, 2006). According to Sacerdoti (2005) in Habtamu et al. (2013), financial institutions such as microfinance and the banking systems in Africa are not in a position in providing enough financial support to the expansion of micro and small businesses. MUDC (2013) also identified that financing has become a principal challenge to small scale enterprises in Ethiopia; except City administrations and regional microfinance institutions, their savings and family supports, banks in Ethiopia do not provide finance in the form of loan to MSE's due to collateral obligations and other requirement.

\subsubsection{Lack of Working Premises}

Working premises with least leasing price adjustment is the first requirement and taken as mandatory to the government (GFDRE, 1997 and 2011). According to the three years performance report of 
FMSEA (2005), the government has supplied 23,263,938 Sq. kilometers land to buildings, sheds and displaying places. Although these efforts have been make, it is the second ranked challenges in regional towns and the major ones in Addis Ababa (Habtamu, et al., 2013; MUDC, 2013). Thus, the problem requires attention to gain SSE's expected benefit.

\subsubsection{Lack of Managerial and Technical Skills}

The problems of MSE's management arises from the limited knowledge and ability of the owner or shortage of competent staff to advice the owner on management policies (Stephen \& Wasiu, 2013). Decision-making skills, sound management and accounting practices are very low for SSE operators in developing countries (Aremu \& Adeyemi, 2011). In addition, lack of managerial skills leads to problems in production due to lack of coordination of production process, and inability to troubleshoot failures on machinery and/or equipment's and they cannot afford to employ specialists in the fields of planning, finance and administration (CLEP, 2006).

\subsubsection{Lack of Adequate Market}

Marketing knowledge is important for the promotion, growth and development of small-Scale enterprises. In this regard, the Ethiopian government has formulated MSE's strategies to ease marketing challenges by creating inter-linkage mechanisms with other institutions, providing training on marketing, developing export support programs and marketing information center (MoTI, 1997). However, inability to sell the products and services; lack of adequate marketing channels, and lack of marketing skills are the problems to the starting of business and further growth of the sector (MUDC, 2013; MoFED, 2011).

\subsubsection{Inadequacy of Inf rastructure Facilities}

A research conducted by Daniel (2012) stated that unfavorable roads, power interruption, shortage of water, and inaccessible telecommunications are the major challenges and without which primary, secondary and tertiary production cannot function. Furthermore, Habtamu et al. (2013) indicated that SSE's operating with available infrastructure facilities has higher probability of long lasting existence and growth as compared to those SSEs that are operating without adequate infrastructures; and electric power interruption and inadequate water supply in Ethiopia was highly affected the growth of the business. Therefore, emphasis should be give since thesuccess or failures of SSE's business growth and development depend on the availability and efficiency of infrastructure utilization.

\subsubsection{Erratic Supply of Raw Materials}

Linking SSEs to production input suppliers, improving suppliers' capacity and regular supply of quality information on input supply sources have positive effects on the success of SSE's (Siva, 2012). As MUDC (2013) has pointed out one of the major problems, constraining the SSE's development in Ethiopia was found to be erratic supply of raw materials. To ameliorate such a problem, an aggressive strategy needs to be craft to promote business ventures, which supply inputs, by local and international investors.

\subsubsection{Regulatory Constraints}

Registration and licensing, and the extent of government official involvement and accessibility of rules and regulations have impacts on MSE's. According to Dlitso, K., and Peter Q. (2000), high startup costs for licensing and registration requirements, cost of settling legal claims and excessive delays in court proceedings can impose excessive and unnecessary burdens on MSE's operations. Even though registration and licensing helps SSE's to have legality rights, and to reduce the prevalence of informality, more than 12\% of MSE's in Addis Ababa didn't have registration license (MUDC, 2013).

\subsubsection{Capital Shortage}

The author observes that small-scale enterprises have serious financial problem in at least three respect of: a) Securing funds in small amount at rates comparable with those paid by large industries. b) Building and manufacturing adequate financial reserves c) Securing long term equity capital.

\subsubsection{Inflation}

Despite the fact that cost of capital is higher for the small-scale manufacturer, the effect is even compound by raising inflation rate. 


\subsubsection{Inadequate Education and Skills}

Education and skills needed to run micro and small enterprises. Research shows that the majority of the carrying micro and small enterprises in Iran are not quite well equipped in terms of education and skills. The study suggests that those with more education and training are more likely to be successful in the SME's sector (King and McGrath, 2002). As such, for small businesses to do well in Iran, people need to be well inform in terms of skills and management. SMEs appear to be doing well with the sprouting of many commercial colleges offering various computer applications. Further, studies show that most of those running SMEs have at least attained college level education.

\subsubsection{Lack of Managerial Training and Experience}

Many SMEs owners or managers lack managerial training and experience. The typical owner or managers of small businesses develop their own approach to management, through a process of trial and error. As a result, their management style is likely to be more intuitive than analytical, more concerned with day-to-day operations than long-term issues, and more opportunistic than strategic in its concept. Although this attitude is the key strength at the start-up stage of the enterprise, because it provides the creativity needed, it may present problems when complex decisions have to be make. A consequence of poor managerial ability is that SME owners are ill prepared to face changes in the business environment and to plan appropriate changes in technology. The majority of those who run SMEs are ordinary lot whose educational background is sadly lacking. Hence, they may not be well equipped to carry out managerial routines for their enterprises (King and McGrath, 2002).

\section{RESEARCH METHODOLOGY}

\subsection{Research Design}

The study was descriptive research design, whose purpose was, to examine Factors affecting of smallscale enterprise the case of restaurants and hotels business in the raya Azebo Wereda southern Tigray. The study was employ qualitative and quantitative research approach; particularly descriptive sample survey was select for the appropriateness with cross sectional of the study. After the data obtain from questionnaires, the research was analyze. The target populations of the study was owners of restaurants and hotels business only. The research project is going to apply both primary and secondary data sources. The primary data was collect using survey questionnaire from the concerned bodies (owners of restaurants and hotels business the three-sub city in Raya Azebo). In addition to this, secondary data was collect from different sources such as documents, other research findings, and reports, in order to support the primary data by some related theoretical concepts.

\subsection{Description of the Study Area}

This study was conduct at the Raya AzeboWereda. Raya AzeboWereda is located around in between the Hintalo Wejerat and Alamata the south Tigray region. It found $127 \mathrm{Km}$ far from Mekelle to south direction. This study focused factors affecting of restaurant and Hotel business.

\subsection{Target Population}

The target populations of the study are the owners of small-scale business who engaged in restaurant and Hotel. Also in the study area, have eight sub towns but this study was conduct in three big towns, which found in that Wereda (mohoni, may chew and Korem). The reason to select these areas is due to the availability of full document, registered small businesses scale enterprise, and has large number of restaurants and hotel businesses. Therefore, these three towns have 311 restaurant and hotel businesses.

\subsection{Sampling Method}

Normally, accurate information about a given population will expect to be obtaining from a census study. However, due to large number of population size, in many of the cases, a complete coverage of a population is not possible. Thus, sampling is one of the methods, which allows the researcher to study a relatively small number of units representing the whole population (Saratnakos, 1998).

The study will be used both probability and Non-probability sampling design. The Non-probability sampling will be used Judgmental or purposive sampling method to select from five-sub cities. 
Therefore, the researcher will be selected mohoni, maychew, and Korem since in these sub city available highly small business. In addition to this, a stratified random sampling method was use the study to select the number of sample respondents proportionally from each stratum. After this, the researcher was use systematic sampling method to select the respondents from each university. Primarily, sample size of the population was determine by using the formula below (wotson J., 2001)as follow:

$$
\begin{aligned}
& n=\frac{\left(\frac{P[1-P]}{\frac{A^{2}}{Z^{2}}+\frac{P[1-P]}{N}}\right)}{R} \\
& =\underline{0.5(1-0.5) \quad 0.25} \\
& \underline{0.05^{2}}+\underline{0.5(1-0.5)}=\underline{.0001454628}=\underline{171.8652}=\underline{\mathbf{1 8 1}} \\
& \begin{array}{llll}
1.96^{2} & 311 & .95 & .95
\end{array}
\end{aligned}
$$

Where: $\mathrm{n}=$ sample size required

$\mathrm{N}=$ number of people in the population

$\mathrm{P}=$ estimated variance in population, as a decimal: $(0.5$ for $50-50,0.3$ for $70-30)$

$\mathrm{A}=$ Precision desired, expressed as a decimal (i.e., $0.03,0.05,0.1$ for $3 \%, 5 \%, 10 \%$ )

$\mathrm{Z}=$ based on confidence level: 1.96 for $95 \%$ confidence, 1.6449 for $90 \%$ and 2.5758 for $99 \%$

$\mathrm{R}=$ Estimated Response rate, as a decimal

In order to proportionally distributed the samples among the strata the formula below was implemented (Yamane's, 1967)

$\mathrm{n}_{\mathrm{h}}=\left(\mathrm{N}_{\mathrm{h}} / \mathrm{N}_{\mathrm{s}}\right) \mathrm{n}$

Where: $\mathrm{n}_{\mathrm{h}=}$ Sample size from each stratum

$\mathrm{N}_{\mathrm{h}}$ = Total population from each stratum

$\mathrm{N}_{\mathrm{s}}=$ Total population of the sum of strata for the study

$\mathrm{n}=$ Total sample size from the study population

Table3.1. Proportional Sample Size from Each Stratum

\begin{tabular}{|l|l|l|l|}
\hline NO & Sub City & Number of business in Sub city & Sample size from each sub city approximate \\
\hline $\mathbf{1}$ & Mohoni & 132 & $(181 / 311)^{*} 132=\mathbf{7 7}$ \\
\hline $\mathbf{2}$ & May chew & 118 & $(181 / 311)^{*} 118=\mathbf{6 9}$ \\
\hline $\mathbf{3}$ & Korem & 61 & $(181 / 311)^{*} 61=\mathbf{3 5}$ \\
\hline \multicolumn{2}{|l|}{ TOTAL } & $\mathbf{3 1 1}$ & $\mathbf{1 8 1}$ \\
\hline
\end{tabular}

Source: MSE's Office 2017

\subsection{Sources of Data}

To collect consistent data and to reach to the targeted solution of the problem, the study was used both primary and secondary sources of data. The primary data was collect from the owners of restaurant and hotel business, of raya AzeboWereda. The secondary data was collect from various reports, Journals, and other written materials, which are available in the study area.

\subsection{Data Collection Method}

The study was questionnaire used to get primary data. In this regard, the questionnaires used to collect relevant information from owners of the restaurant and hotel business Raya Azebo Wereda by using open and close end questions. Secondary data was also collect from the available documents of the Raya Azebo Wereda about the small business activity. 
The questionnaire had three sections. The first section was contains questions associated with the general demographic characteristics of the sample respondents. The second section was deals with questions related internal factors affecting of restaurant and hotel. Finally, part of the questionnaire contains questions regarding to encompass questions associated with external factors affecting of restaurant and hotels. For the sake of made the questionnaire clear and easily understanding, it was develop English version, later translate in to Tigrigna version.

\subsection{Methods of Data Analysis}

After the data was collect from stratified random sampling method employees, was summarize by using Excel and transferred to SPSS Version 20was analyze in terms of descriptive statistics such as Percentages and Mean. The output obtained from the software was present by using tabulation of data followed by the analysis. Mean scale, as a measure of central tendency was use to show where the majority of responses concentrate i.e. nearer to which scale the representative middle value of responses found.

\section{RESUlTS AND DISCUSSIONS}

This chapter deals with the presentation, analysis and interpretation of data collected through questionnaires, information collected from owners of the businesses of restaurants and hotel business. The questionnaires distributed to sampled Small-scale enterprise owner of restaurant and hotel business in Raya Azebo Wereda town specifically in three-sub town of Wereda. In conducting the study, 181 questionnaires distributed out of which 169were return and answer.

\subsection{Response Rate}

The information concerning the assessment of factors affecting of restaurant and hotels businesses in case of Raya Azebo Wereda was collect from the owners of the businesses. Accordingly, 181 questionnaires distributed out of which 169 returned and answered. After data collection, the researcher coded it in SPSS version 20. For analysis purpose, descriptive statistical tool like frequency, tables mean and standard deviation etc. was use.

\subsection{Profile of Participants}

Table4.1. Characteristics of the Owners

\begin{tabular}{|l|l|l|l|}
\hline Characteristics & Category & Frequency & Percentage \\
\hline Sex & Male & 36 & 21.3 \\
\cline { 2 - 4 } & Female & 133 & 78.7 \\
\cline { 2 - 4 } & Total & $\mathbf{1 6 9}$ & $\mathbf{1 0 0}$ \\
\hline Age & $18-25$ & 27 & 16 \\
\cline { 2 - 4 } & $26-35$ & 96 & 56.8 \\
\cline { 2 - 4 } & $36-40$ & 21 & 12.4 \\
\cline { 2 - 4 } & $41-45$ & 16 & 9.5 \\
\cline { 2 - 4 } & Above 46 & 9 & 5.3 \\
\cline { 2 - 4 } & Total & $\mathbf{1 6 9}$ & $\mathbf{1 0 0}$ \\
\hline Educational & Uneducated & 43 & 25.4 \\
\cline { 2 - 4 } & Elementary & 49 & 29 \\
\cline { 2 - 4 } & High school & 68 & 41.3 \\
\cline { 2 - 4 } & Diploma & 6 & 3.6 \\
\cline { 2 - 4 } & Degree & 3 & 1.8 \\
\cline { 2 - 4 } & Total & $\mathbf{1 6 9}$ & $\mathbf{1 0 0}$ \\
\hline
\end{tabular}

Source: Own Survey 2017

The above table4.1 proves the demographic characteristics of respondents. In case of gender distribution, Male respondents account for $21.3 \%$ while females accounted $78.7 \%$. This shows majority of respondents was female. The age distribution also, majority of them usually $56.8 \%$ are under the age from 26-35 years followed by $18-25$ which accounted $16 \%$. The remaining $27 \%$ are the collective age of 36-40, 41-45, and above 46 years. From this finding it can be concluded that, the age from 18-35 are covered in the study.

Concerning the level of education, Most of the respondents are high school followed by elementary school and uneducated which accounted $41.3 \%, 29 \%$ and $25.4 \%$ respectively. Only 5.4\% respondents 
Factors Affecting the performance of Small-Scale Enterprise (Restaurant and Hotels) Inraya Azebo Wereda: The Case of Mohoni, Maychew and Korem

are diploma and degree holders. From this finding, it can be conclude that there is very few involvement of diploma and degree holders' participation in restaurant and hotel business.

Table4.2. Characteristics' of the Enterprise

\begin{tabular}{|c|c|c|c|}
\hline Characteristics & Category & Frequency & Percentage \\
\hline \multirow{3}{*}{ Form of your business } & Proprietorship & 161 & 95.3 \\
\cline { 2 - 4 } & Partnership & 8 & 4.7 \\
\cline { 2 - 4 } & Total & $\mathbf{1 6 9}$ & $\mathbf{1 0 0}$ \\
\hline \multirow{2}{*}{ Types of business enterprise } & Restaurant & 68 & 40.2 \\
\cline { 2 - 4 } & Coffee house & 101 & 59.8 \\
\cline { 2 - 4 } & Total & $\mathbf{1 6 9}$ & $\mathbf{1 0 0}$ \\
\hline \multirow{2}{*}{ Entrepreneurship training programs } & Yes & 18 & 10.7 \\
\cline { 2 - 4 } & No & 151 & 89.3 \\
\cline { 2 - 4 } & Total & $\mathbf{1 6 9}$ & 8.3 \\
\hline & Yes & 14 & 91.7 \\
\cline { 2 - 4 } & No & 155 & $\mathbf{1 0 0}$ \\
\cline { 2 - 4 } & Total & $\mathbf{1 6 9}$ & \\
\cline { 2 - 4 } & & & \\
\hline
\end{tabular}

Source: Own Survey 2017

As the above table 4.2 shows about the characteristics of the enterprise, in case the form of businesses enterprise, almost all (95.3\%) of them replied, as they are proprietorship. Only 4.7\% respondents are involved in partnership. Furthermore, concerning entrepreneurship-training program, $89.3 \%$ of respondents replied, as they are not perform in any training program. Only $10.7 \%$ respondents are obtaining training when they start business.

The factors of affecting the owners of businesses because training is more likely to be successful business and solve different problem in the SSE's sector. Similar findings were reported by authors such as (King and McGrath, 2002), in case of preparing business plan during the startup of the business, almost all respondents replied, as they did not prepare any plan.

\subsection{The Factors Affecting of Restaurant and Hotel Businesses}

Table4.3. Financial problem of Restaurant and hotels

\begin{tabular}{|c|c|c|c|}
\hline Variables & Category & Frequency & Percentage \\
\hline \multirow[t]{5}{*}{ Source of Finance } & Own personal saving & 109 & 64.5 \\
\hline & Bank & 3 & 1.8 \\
\hline & Micro finance & 25 & 14.8 \\
\hline & From the relative & 32 & 18.9 \\
\hline & Total & 169 & 100 \\
\hline \multirow{6}{*}{$\begin{array}{l}\text { There is adequate current capital in the } \\
\text { business }\end{array}$} & Strongly agree & 7 & 4.1 \\
\hline & Agree & 23 & 13.6 \\
\hline & Medium & 50 & 29.6 \\
\hline & Disagree & 53 & 31.4 \\
\hline & Strongly disagree & 36 & 21.3 \\
\hline & Total & 169 & 100 \\
\hline \multirow[t]{6}{*}{ Bad debt is affected the business } & Strongly agree & 77 & 45.6 \\
\hline & Agree & 72 & 42.6 \\
\hline & Medium & 14 & 8.3 \\
\hline & Disagree & 5 & 3 \\
\hline & Strongly disagree & 1 & 0.6 \\
\hline & Total & 169 & 100 \\
\hline \multirow[t]{6}{*}{ There is Shortage of credit } & Strongly agree & 31 & 18.3 \\
\hline & Agree & 49 & 29 \\
\hline & Medium & 40 & 23.7 \\
\hline & Disagree & 32 & 18.9 \\
\hline & Strongly disagree & 17 & 10.1 \\
\hline & Total & 169 & 100 \\
\hline
\end{tabular}

Source: Own Survey 2017 
The above table 4.3 illustrate about the finance of the business owners. Thus, $64.5 \%$ of them reply as they acquire from personal saving. Another $18.9 \%$ are reply as they acquire from relatives. Only $16.8 \%$ are says from micro finance institutions and banks.

Furthermore, the table presents the financial problem faced to restaurant and hotel. Therefore, respondents asked to decide with the give statements by saying strongly agree, agree, medium, disagree, and strongly disagree. With the adequacy of current capital in the business, $31.4 \%$ of respondents disagree with the statement, $29.6 \%$ medium, $21.3 \%$ strongly disagree. Only $13.4 \%$ and $4.1 \%$ are agreed and strongly agreed with the statements. From this finding it would be conclude that majority of the respondents are usually disagree and medium followed by strongly disagree with the statement. Besides the result shows shortage of current capital to run the business is the main challenge of businesses.

In addition to this with the statement "bad debit affect the business", most of the respondents $45.6 \%$ replied strongly agree, $42.6 \%$ agree. Few numbers of respondents are $(8.3 \& 3 \%)$ replied medium and disagree. Generally, they are approaching to disagree.

Moreover, the table illustrates about the shortage of credit from different sources. Hence, $29 \%$ respondents agree, $23.7 \%$ medium, 18.9 disagree and 18.3 strongly agree with the statement. This implies that most of the respondents are under agree and medium.

The last point almost all respondents replies to the open-ended question for their negative response hence, the financial institution (like bank and micro financial institution) are long process, bureaucracy, and high interest rate, also private money lenders are high tax rate and small size loan.

This implies business owners they cannot easily and on time acquire money to solve the different problems of restaurant and hotel business. Financial institutions such as microfinance and the banking systems in Africa are not in a position in providing enough financial support to the expansion of micro and small businesses. The result is in line with the findings of (Habtamu et al. (2013)

Table4.4. Market and marketing problems

\begin{tabular}{|l|l|l|l|l|}
\hline \multicolumn{1}{|c|}{ Variables } & Minimum & Maximum & Mean & Std. Deviation \\
\hline Product/service design not based on customer preference & 1 & 5 & 2.85 & .802 \\
\hline Lack of demand forecasting & 2 & 5 & 4.01 & .967 \\
\hline Poor customer handling and relation ship & 1 & 5 & 3.98 & 1.096 \\
\hline Inability to modify existing product & 1 & 5 & 3.57 & 1.219 \\
\hline Inability to promote the product & 1 & 5 & 3.41 & 1.445 \\
\hline Lack of skill to set comparatives price & 1 & 5 & 3.55 & 1.112 \\
\hline
\end{tabular}

Source: own survey 2017

The above table 4.4 represents the mean value of each statements computed based on the five point likert scale which questions related to marketing factors in restaurant and hotel business. Therefore, the mean value of lack of product/service design is 2.85 , Lack of demand forecasting(4.01), Poor customer handling and relationship (3.98), Inability to modify existing product (3.57), Inability to promote the product (3.41), and Lack of skill to set comparatives price (3.55).

In this case, the highest mean represents the main challenge whereas the low mean represents the lowest challenge to the restaurant and coffee house business. Then almost all are usually challenges but lack of demand is the main challenge for the performance of these businesses in the market with a mean value of 4.01 followed by poor customer handling and relationship with a mean value of 3.98. In contrary, only one, which is product/service design according to customer's preference, is the lowest challenge with a mean value of 2.85 .

The below figure 4.1 is show market location of the business owners. Thus, $56.8 \%$ of them reply the businesses are located in the right market location, and $43.2 \%$ of owners answered the businesses are not positioned in the right market location.

This implies that majority of the respondents are market location not affecting to the business since the business found in right market. 


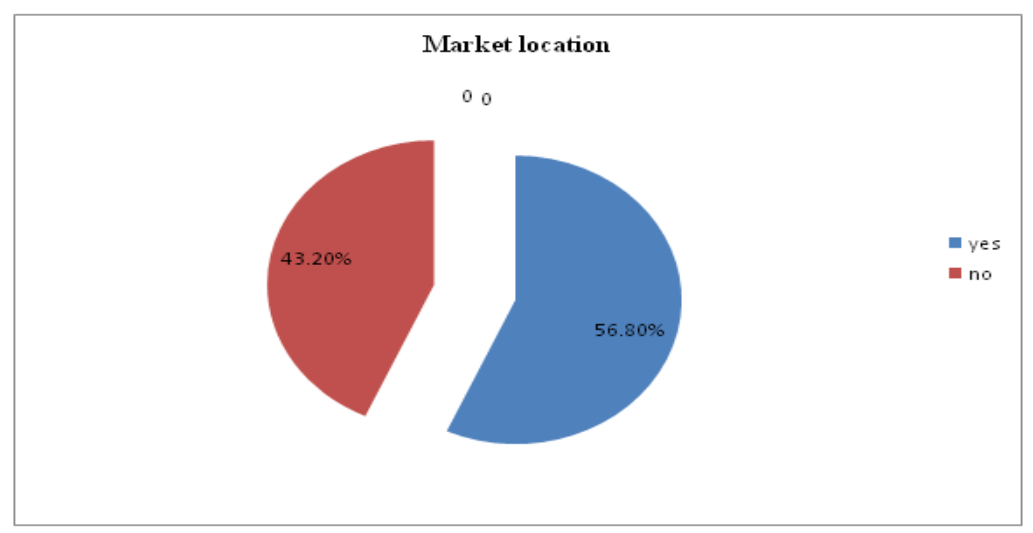

Figure4.1. Market Location

Source: own survey 2017

Table4.5. Legal and Managerial problems in the Performance of Restaurant \&hotels

\begin{tabular}{|l|l|l|l|l|}
\hline Variables & Minimum & Maximum & Mean & Std. Deviation \\
\hline Implementation of rule and regulation & 1 & 5 & 3.92 & 1.147 \\
\hline High tax rate & 1 & 5 & 3.97 & .896 \\
\hline Managerial problem & 1 & 5 & 3.58 & 1.173 \\
\hline allow to give licensing & 1 & 3 & 3.83 & .894 \\
\hline
\end{tabular}

Source: own survey 2017

The above table 4.5 stands for the mean value of each statements computed based on the five point likert scale, which questions related to Legal, and managerial factors affecting the performance of restaurant and hotels business. Hence, the mean value Implementation of rule and regulation is 3.98, High tax rate 3.97, Managerial problem 3.58, and allow giving licensing 3.85.

In this case, the highest mean represents affecting the performance of restaurant and hotels business whereas the low mean represents the lowest affecting the Performance to the restaurant and hotels business legal and managerial factors. Then almost all are usually affecting the performance of restaurant and hotels business but Implementation of rule and regulation is the main problem for the performance of these businesses in the market with a mean value of 3.92 followed by high tax rate with a mean value of 3.97 and let to give licensing with the mean of 3.83.

This involves High start-up costs, allow giving the licensing and can impose excessive and unnecessary burdens on SSE's operations. However, they understand licensing helps, SSE's to have legality rights, and to reduce the prevalence of informality. Similar findings were reported by authors such as (MUDC, 2013), Dlitso, K., and Peter Q. (2000),

The below Figure 4.2 illustrates the Fairness of Tax of the study area. Thus, $88 \%$ of them replied as the tax collectors are collected unfair. The minority which is $12 \%$ said that the tax collectors are fair during they collect tax.

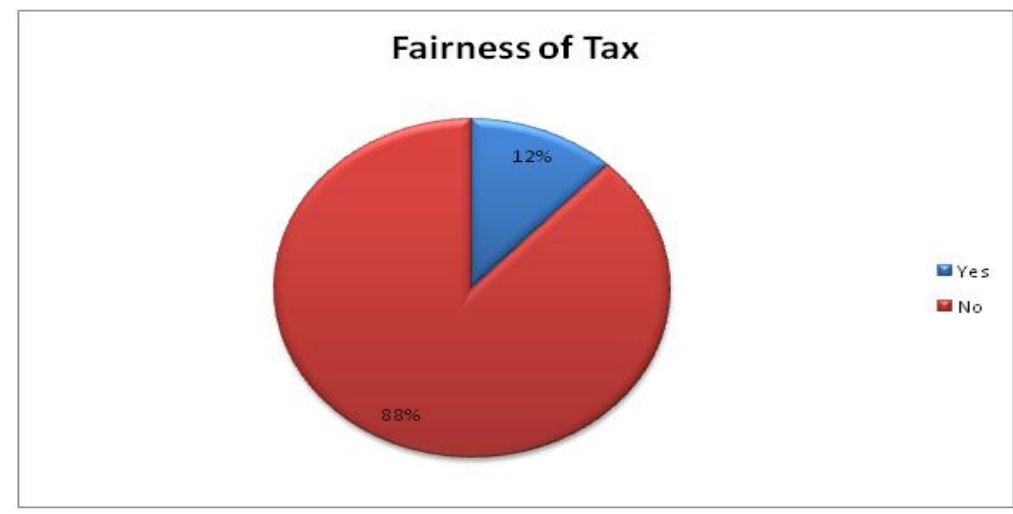

Figure4.2. Fairness of Tax

Source: own survey 2017 
In addition to this the respondents replies to the open-ended question for their negative response that they observe the following from the tax collectors; at the time of tax collects doing something similar to biasness, corruption, lack of skill tax collectors, notional and less considering about how to collect tax thus which business is doing well or not.

Table4.6. Problems of Infrastructures

\begin{tabular}{|c|c|c|c|c|}
\hline Variables & Minimum & Maximum & Mean & Std. Deviation \\
\hline Electricity & 1 & 3 & 1.31 & .537 \\
\hline Water & 1 & 3 & 1.35 & .569 \\
\hline Telephone & 1 & 5 & 3.08 & .991 \\
\hline Transport & 1 & 5 & 2.62 & .969 \\
\hline
\end{tabular}

Source: Own Survey 2017

The above table 4.6 represents the mean value of each declaration computed based on the five point likert scale, which questions related to access and quality of the infrastructures. For that reason, the mean value of access and quality of electricity is (1.31), access and quality of water (1.35), access and quality transport(3.08), and access and quality telephone (2.62).In this case, the lowest mean represents the main factors affecting whereas the highest mean represents the lowest factors affecting to the restaurant and hotels business.

Then almost all are usually factors affecting since lack of access and quality infrastructure in the study area but access and quality of electricity and water are the main factors affecting for the performance of these businesses to do effectively and efficiently. With a mean value of 1.31 followed by access and quality of water with a mean value of 1.35 . In opposing, only one that is approaching to high availability of transportations accordingly the access of transportations is the lowest challenge with a mean value of 3.08 .

This involve an environment with very poor infrastructure which constitutes a barrier to entry, hinders domestically competitiveness and the business is not doing properly similar findings were reported by authors such as Daniel (2012).

Table4.7. Factors of Competition Affecting In Restaurant and Hotels

\begin{tabular}{|l|l|l|l|l|}
\hline Variables & Minimum & Maximum & Mean & Std. Deviation \\
\hline There is low level of competition from the compotators & 1 & 5 & 2.02 & .767 \\
\hline The able to sustain competition enterprise & 1 & 5 & 2.62 & .969 \\
\hline $\begin{array}{l}\text { The enterprise is able to afford production at reasonable price } \\
\text { so, that it can with stand in competition }\end{array}$ & 1 & 5 & 3.85 & 1.202 \\
\hline $\begin{array}{l}\text { The enterprise have regular customer and the customer traffic } \\
\text { is good enough get profit }\end{array}$ & 1 & 5 & 2.01 & .687 \\
\hline
\end{tabular}

Source: Own Survey 2017

The above table 4.7 display that the denoted value of each statement computed stand on the five point likert scales which questions associated computational factors affecting on the restaurant and hotels business. As a result the signify value level of competition with other related businesses is 2.02, business owners able to sustain the competition of enterprise is 2.62 , the firms able to afford production at reasonable price to position on competition is 3.85 , and about the enterprise have regular customer respondents accounted 2.01. Contained the lowest mean represents the main factors affecting of restaurant and hotels business while the highest mean represents competition factors affecting of restaurant and hotels business is low.

This finding typically the level of competition in the study area is very high, the business owners are not able to sustain the businesses by the diverse things, and the respondent replied they have not regular customer and they have not good enough get profit.

In contrary respondents replied the enterprise performed able to afford production at reasonable price accordingly, it can with stand in competition of with the related businesses like restaurant and hotels business. 
Factors Affecting the performance of Small-Scale Enterprise (Restaurant and Hotels) Inraya Azebo Wereda: The Case of Mohoni, Maychew and Korem

Table4.8. Problems of Operational in Restaurant and hotels

\begin{tabular}{|l|l|l|l|l|}
\hline Variables & Minimum & Maximum & Mean & Std. Deviation \\
\hline $\begin{array}{l}\text { The business provide variety of products/service } \\
\text { to cater the needs of all types of customers }\end{array}$ & 1 & 5 & 2.95 & .758 \\
\hline $\begin{array}{l}\text { The business has enough space to accommodate } \\
\text { the fluctuations in customers' arrival }\end{array}$ & 1 & 5 & 2.90 & .917 \\
\hline $\begin{array}{l}\text { The business has enough service facilities in } \\
\text { meeting out the fluctuations in the number of } \\
\text { customers }\end{array}$ & 1 & 5 & 2.71 & .759 \\
\hline $\begin{array}{l}\text { The business has enough utensils to meet out the } \\
\text { fluctuations in customers arrival }\end{array}$ & 1 & 5 & 2.72 & .636 \\
\hline $\begin{array}{l}\text { How do you see the ambience (atmospheric } \\
\text { conditions) of the restaurant and coffee house are } \\
\text { attractive and itself promoting customers }\end{array}$ & 1 & 5 & 3.27 & .911 \\
\hline
\end{tabular}

Source: Own Survey 2017

The above table 4.8 stands for the mean value of each statements computed based on the five point likert scale, which questions interconnected to operational factors affecting of restaurant and hotels business. Therefore the mean value preparing product/service of the business to cater the need of customer is 2.95 , enough space to accommodate customers' arrival is 2.90 , and availability of enough service facilities is 2.71 , availability enough utensils is 2.72 , lack and atmospheric conditions is 3.27.In this case, the highest mean represents the low factors affecting whereas the low mean represents the main factoring affecting to the restaurant and hotels business.

Then almost all are typically shows from the above table factors affecting of restaurant and hotels business. However, lack enough service facilities; lack enough utensils, and enough space to accommodate the fluctuations in customers' arrival are the main challenge for the performance of these businesses in the operational with a mean value of 2.71, 2.72, and 2.90 respectively followed by provide products/service to cater the needs of all customers with value mean 2.95 . In differing, only one, which is low ambience according to operational preference, is the lowest challenge with a mean value of 3.27 .

From this finding it can be concluded that majority of the respondents said that factors affecting of the operations are lack of enough space to accommodate customer arrival, and lack of enough utensils.

Table4.9. Production/ Service Interruptions

\begin{tabular}{|l|l|l|l|l|}
\hline Variables & Minimum & Maximum & Mean & Std. Deviation \\
\hline There is lack of power availability & 1 & 5 & 4.51 & .782 \\
\hline There is Lack of manpower & 1 & 5 & 3.41 & 1.028 \\
\hline There is Lack of skilled manpower & 1 & 5 & 3.12 & 1.240 \\
\hline $\begin{array}{l}\text { The business is facing problems with regard to } \\
\text { unavailability of materials }\end{array}$ & 1 & 5 & 3.97 & .908 \\
\hline $\begin{array}{l}\text { Because of lack of additional facilities in the } \\
\text { restaurant and coffee house such as television } \\
\text { etc the restaurant and coffee house losses or } \\
\text { unable to withhold the existing customers }\end{array}$ & 1 & 5 & 3.12 & .837 \\
\hline
\end{tabular}

Source: Own Survey 2017

Above table, 4.9 shows that the mean value of each statement subtracted based on the five point likert scales, which questions related to operational factors affecting, reason for production/ service interruptions in restaurant and hotels business. Consequently, the mean value lack of power availability is 4.51 ; lack of work force is 3.41 , facing problem with regarding unavailability of material is 3.97, and lack of additional facilities is 3.12. In this case, the highest mean represents the main factors affecting but the low mean represents the low factors affecting to the restaurant and hotels business.

Then it can be conclude that more or less all are factors affecting to the restaurant and hotels business reason for production/ service interruptions but the majority respondents replied lack of power availability and unavailability of materials with value of mean 4.51, and 3.97 respectively reason for production/ service interruptions. 
Moreover, this indicates that there is a potential gap with access of power availability, materials and work force to the business development services, and product interruptions. Authors such as Habtamu et al. (2013) and MUDC (2013) reported similar findings.

Table4.10. Contirbution of MSE's

\begin{tabular}{|l|l|l|l|}
\hline Statement & Responses & Frequency & Percentage \\
\hline \multirow{2}{*}{$\begin{array}{l}\text { Successes depend on the support provider MSE's } \\
\text { office }\end{array}$} & Very high & - & - \\
\cline { 2 - 4 } & High & 3 & 1.8 \\
\cline { 2 - 4 } & Medium & 23 & 13.6 \\
\cline { 2 - 4 } & Low & 83 & 48.5 \\
\cline { 2 - 4 } & Very low & 61 & 36.1 \\
\cline { 2 - 4 } & Total & $\mathbf{1 6 9}$ & $\mathbf{1 0 0}$ \\
\hline Contrbution office of MSE's & good improvement & - & - \\
\cline { 2 - 4 } & no change & 128 & 75.7 \\
\cline { 2 - 4 } & Decrease & 41 & 24.3 \\
\cline { 2 - 4 } & Total & $\mathbf{1 6 9}$ & $\mathbf{1 0 0}$ \\
\hline
\end{tabular}

Source: Own Survey 2016

The above table 4.10, Show about the support provider and contrbution MSE's office.

Therefore, respondents are inquiring to decide with the give statements by saying very high, high, medium, low, and very low. With the successes, depend on the support provider MSE's office, $48.5 \%$ of respondents low with the statement, $36.1 \%$, and very low $21.3 \%$ medium. Only $1.8 \%$ is high with the statements. From this finding it can be concluded that majority of the respondents are usually low and very low followed by medium with the statement. Generally, they are approaching to low of supporting provider from MSE's office.

Furthermore, the respondents are inquiring to decide with the give statements by saying good improvement, no change and decrease. With this contribution of MSE's office $75.7 \%$ of respondents, no change with statement and $24.3 \%$ of respondents decrease with statement. From this it can be conclude that the approaching to no change the contribution of MSE's office.

\section{SumMary, CONCLUSIONS AND RECOMMENDATIONS}

\subsection{Summary and Conclusion}

This research is conduct in Raya Azebo Wereda in different town with the prime intent of investigating the factors affecting of restaurant and hotels business. More specifically, the researcher tried to scrutinize the attempted to investigate what are the business owners of restaurant and hotels problems in the Raya Azebo Wereda.

Data collected from primary sources mainly through questionnaires. Secondary sources like journals, books, the internet, and other published materials were also use to obtain background information. Majority of owners of restaurant and hotels business are between the ages of 26-35 and females. From this it can be drawn that majority of the restaurant and hotels business owners age are among the ones the country is desired economic development can be attained by. The majority of restaurant and hotels business are uneducated and secondary school. There is very few involvement of diploma and degree holders' participation in restaurant and hotels business. The level of education indicates that they need a higher level of education to run the business industry and other sectors and to accept easily new ideas.

Evidence from the owners of the business almost all of them the businesses are proprietorship. Furthermore, the business owners are before and after starting of the firm the government or MSE's of the study area, more probably not acquire entrepreneurship-training program. The training is more likely to be successful business and it can show the technique how to solve different factors affecting in the restaurant and hotels business. Also in case of preparing business plan during the startup of the business, almost all respondents replied, as they did not have any plan at the beginning. This indicates business plan consequence to the restaurant and hotels business since business plan follows objective, goal, vision and all financial statements.

The owners of the business replied that they have no enough capital to run the business and very high suffer with bad debt since when owners to solve shortage of capital they acquire long process, 
bureaucracy, high interest rate from the financial institution and private money leaders. Financial institutions such as microfinance and the banking systems are not in a position as long as enough financial support to growth of restaurant and hotels business.

The result from the analysis of markets distress the performance restaurant and hotels business, which is business owners based on the different things like especially Poor customer handling, Lack of demand forecasting, and Inability to modify existing product affects the performance of the business. The restaurant and hotels business the study area affects the performance comes from the business owners, which is lack of properly doing the market movement.

Moreover the main Legal and managerial problems are rule and regulation, high tax rate also affecting the performance of the business and only small numbers of the business owners said that the tax collectors are collected fair. This involves restaurant and hotels business factors the performance by corrupted and unskilled members of local government.

The likert-scale response analysis Access and quality of the infrastructures approximately all respondents replied very poor infrastructure specially availability of electricity and water. This engage in the study area have very poor infrastructure which comprise the businesses are fail while the businesses are not doing effectively and efficiently. In addition to this Contirbution office of MSE's is can be conclude that the approaching to no change thus, there is no contribution to the restaurants and hotels business.

The respondent replied level of competition in the study area is very high, the business owners are not able to sustain the businesses and they have not regular customer. In contrary respondents replied the enterprise performed able to afford production at reasonable price accordingly, it can with stand in competition of with the related businesses like restaurant and hotels business. This involves high level of competition in the study area since restaurant and hotels business it have no regular customer.

Furthermore, the study had revealed that restaurant and hotels in operating the study area have been confronting with a number of challenges. Among those challenges the major ones include lack of power availability, unavailability of materials, lack of enough utensils, lack of additional facilities and enough space to accommodate the fluctuations in customers' arrival in addition to this more of the business owners they have lack quality service facilities.

The restaurant and hotels business are it have possible gap with access of power availability, materials, enough space and work force reason for product/service interruptions.

From the finding response analysis of owners, wish to wards the growth opportunities to the restaurant and hotels business. Therefore owners make believe wish to wards the growth opportunities to the restaurant and hotels business similar to diversify the business, enlarge to medium enterprise, produce quality product and understand how give best service to customer, reduced cost, increased incomes, and various opportunities.

The result from the interview main face up to the business owner in the Wereda, less quality product produce, poor handling customer and the major is the owners enter into market without investigation, and MSE's haven't given regular entrepreneurship program.

Furthermore the owners closed the business by the reason (like dead, wastage, high tax, illness and work bereft) but support to the enterprises, the office respond that as there is promising efforts, kaizen and financial supports made to improve the support given partly.

\subsection{Recommendations}

$>$ Of the confirmed, most important owners of restaurant and hotels business are between the ages of 26-35 and females therefore, the majority young age the local, regional and federal government should be focus on providing training all about direction how to run the business and support financial. Especially majority of the owners are uneducated and secondary school so, more focus the training is give hotels to uneducated person. Furthermore, their wife, governments, should give women support and it may concern in deference of finances, motivational encouragement, and advice. 
$>$ From the main factors affecting of restaurant and hotels business are many things on the above lists therefore, to solve their problems since form of partnership is better than proprietorship with regarding to financial strength, risk sharing and economic strength.

$>$ Enterprises operating without business plan are difficult therefore, advised to prepare business plan. Product/service providers of the enterprises had better convince and aid such enterprises to prepare business plan. In addition to this the office of MSE's prepare the regularly entrepreneurship training program especially to the new business, consults how to prepare business plan, produce quality product, give training how to customer handling to the owners.

$>$ Although savings are one of the means of accumulation of capital, often savings alone cannot be sufficient for running and expanding business operations, thus, there is a need for creating lines of credit. The support of MFIs and Banks should be encouraged through varying methods, such as widening the kind or range of collaterals, providing credit by making longer repayment, increase the amount of loan provided for group based lending.

$>$ With regard to marketing support, the following measures need to encourage by the government. These are linking MSE's with medium and large firms to serve as market outlets, Provision of training on quality improvement and cost decline modalities, Provision of information on market opportunities, Construction of display centers and provision of advertising support. Moreover, to make restaurant and hotels business competitive and profitable, increasing the capacity, knowledge, and skill or attitude that enables operators to prepare for production activities, through continuous trainings, experience sharing from successful enterprises, and provision of advice and consultancy should be crucial.

$>$ The tax collectors should be amount of tax determines based on income of the owners and determine tax based of income the local government introduce tax machines at this time reduce corruption and set the price since majority of owners of the business they have not machine.

$>$ Moreover, as long as this sector is expected to contribute more to the growth and transformation plan (GTP 2) of the region and the country, then the government should give priority in distributing electricity, water and transportation by clustering very important MSE's in one particular place. Besides, the enterprise owners should try to seek other alternative source of power other than entirely depending electricity offered by the government such as electric generator.

$>$ The quality and quantity of restaurant and hotels business enterprises products should be high at all times. This will attract more customers and able to sustain. Besides, operators should develop ways of producing at stumpy costs and selling at relatively low price. This will make demand to be high always and win over the competitors.

> The supporting agencies and organizations such as, government and donors need to Strengthen, through providing the necessary incentive and capacity building training to the work forces of the restaurant and hotels towns enterprises establishing unit.

$>$ Appropriate experience sharing activities set by the sub-city restaurant and hotels business support institutions with the integration of MSE's operators. All support institutions should create integration based on common board to provide uniform, fair and immediate managerial and technical support on financial, managerial, training and development and marketing matters.

\section{REFERENCES}

[1] Adeyemi, S.L. \& Aremu, M. A. (2011).Small and Medium Scale Enterprises as A Survival Strategy for Employment Generation in Nigeria. The Journal of Sustainable Development 4,200-206.

[2] Adil Yassin. (2007). Challenges and Constraints of Micro and Small Scale Enterprises in Addis Ababa: The case of 2 Sub-cities' Industrial Zones. MA thesis in Regional and Local Development Studies.

[3] Akande, O. Ojokuku, R. M. (2008). The impact of entrepreneurial skill on small business performance in Lagos-South-Western Nigeria. Paper presented at the international council for smallbusiness world conference. Halifax, Nova Scotia, June 22-25, 2008.

[4] Aremu, M., A., and Adeyemi, S., L., (2011). Small and Medium Scale Enterprises as a Survival Strategy for Employment Generation. Journal of Sustainable Development, 4 (1), 200-206. (Anon., n.d.)

[5] Arinaitwe, J.K. (2006). Factors constraining the growth and survival of small-scale business: A developing countries analysis. Journal of American Academy of Business, Cambridge, 8(2), 167-178. 
[6] Bernice., K. and Meredith, G. (1997) 'Bernice K. and Meredith G. (1997), Relationships among owner/manager personal values,', Journal of Small business Management vol. 35, no. 2, pp. 37-64

[7] Bates, T. (1995). 'Analysis of suriviva rates among franchise and independent small business start ups', Journal of small Business Management [Electronic], vol. 23, no. 2, pp. 26-36.

[8] Beyene, H.G. (2007).Entrepreneurship and Small Business Management, $2^{\text {nd }}$ edition, Mekelle.

[9] Bowen, M, Morara, M., and Mureithi, S. (2009). Management of Business Challenges Between Small and Micro Enterprises. Kca Journal of Business Management, 2(1), 16-31.

[10] Carter, S. \& Jones-Evans, D. (2006). Enterprise and small business: principles, practice and policy (2. ed.). Harlow: FT Prentice Hall.

[11] CLEP, (2006). Entrepreneurship: Unpublished manuscript, Addis Ababa, Ethiopia.

[12] Daniel, A.S. (2012). Micro, Small and Medium Scale Enterprises in Ghana: Challenges and Prospects: A Case Study of Sekondi-Takoradi Metropolis.

[13] Daniel Woldekidan Elfeta. (2007). Micro and Small Scale Enterprises and their influences in alleviating Urban Poverty in Nekemte City, Oromiya Regional State. MA thesis in Regional and Local Development Studies.

[14] Dalitso, K. and Peter, Q., (2000). The Policy Environment for Promoting Small and Medium-Sized Enterprises in Ghana and Malawi, University of Manchester.

[15] Eshetu Bekele \& Zeleke Worku. (2008). Factors that Affect the Long-term Survival of Micro, Small, and Medium Enterprises in Ethiopia, South African Journal of Economics, Vol. 10, No. 2, pp. 76-81.

[16] Ephrem Setegn (2010). The Role of Micro and Small Enterprises in Poverty Alleviation in Gulele Sub City, Addis Ababa Ethiopia.MA Thesis in public Administration, Addis Ababa University.

[17] FMSEA,(2013). Three years (2003-2005 E.C) Micro and Small Enterprises Performance Report. Addis Ababa. Ethiopia

[18] Fridah, M.M. (2012). 'The challenges facing Small scale women entrepreneurs Acase of kenya', Journal of Business Administration, vol. 3 March, no. 2,

[19] Gebrehiwot A. and Wolday Amha. (2006). Micro and Small Enterprises (MSEs) Finance In Ethiopia: Empirical Evidence. Eastern Africa Social Science Research Review. Volume 22.

[20] Getahun Reta. (2009). The Impact of Micro and Small Scale Enterprises Development Program in Reducing Urban Poverty. MA thesis in Regional and Local Development Studies. RLDS, Addis Ababa University.

[21] GFDRE, (2011). Micro and Small Enterprise Development Strategy: provision framework and Methods of Implementation. Addis Ababa, Ethiopia.

[22] Green, C. J., Murinde, V. \& Kirkpatrick, C.H. (2006). Finance for Small Enterprise Growth and Poverty Reduction in Developing Countries. Journal of International Development.

[23] Habtamu, T., Aregawi, G. and Nigus, A. (2013). Growth Determinants of micro and Small Enterprises: Evidence from Northern Ethiopia. Journal of Economics and Sustainable Development, 4(9), 128-135

[24] Habte, K., (2012). 'Growth and attributing factors of micro and small enterprises the case of wood and metal work in addis ababa town'. PG. Jimma: Jimma university.

[25] Hussmann's, Ralf and Mehran, Farhad. (2005). Statistical Definition of the Informal sector. International standards and National practices. International Labor office, Bureau of statistics, Geneva, Switzerland.

[26] Kangasharju, A. (2000). 'Growth of the smallest: Determinants of small firm growth during strong macro economic fluctuations.', International Small Business Journal [Electronic],vol. 19, no. 1, pp. 28-43.

[27] Keasey, K. Watson, R. (1993). The management of small firms: ownership, finance and Performance. Blackwell, Oxford.

[28] King K, McGrath S: Globalization, enterprise and knowledge. Oxford: Symposium; 2002.

[29] Liedholm, Carl, and Mead, C. Donald. (1999). Small Enterprises and Economic Development: The Dynamics of micro and small enterprises, Rutledge Studies in Development Economics,Volume26, Number 1. January1999. New York.

[30] Mersha, T., Sriram, V, and Hailu, M. (2010). Nurturing Opportunity Entrepreneurs in Africa: Some Lessons from Ethiopia. Journal of Global Business Advancement, 3(2), 155-175.

[31] Meyanathan, S.D. (1994). "Industrial Structures and the Development of Small and Medium Enterprise Linkages: Examples from East Asia". The World Bank

[32] Mezgebe, W., 2012. Problems of Micro and Small Enterprises in Addis Ababa: Kirkos, Kolfe, and Yeka Sub Cities. Volume II, pp. 35-34.

[33] Moutray, Chad. "Recent Research Uncovers Multifaceted Relationship of Entrepreneurship and Local Economic Growth." 
[34] MoTI, (1997).Micro and Small Enterprises Development Strategy. Addis Ababa, Ethiopia.

[35] MUDC, (2013). Survey on Micro and Small Scale Enterprises in Selected Major cities of Ethiopia. Addis Ababa, Ethiopia.

[36] Mulugeta Yohanes. (2011).The Livelihoods Reality of Micro and Small Enterprise Operators: Evidences from Woreda One of Lideta Sub-City, Addis Ababa. MA Thesis in Regional and Local Development Studies. RLDS, Addis Ababa University.

[37] Mwobobia, F. M. (2012). Role of business management into the success and survival of small business: the case of star learning centre in Botswana. International Journal of BusinessAdministration, 3, 1, 93-112.

[38] Palmetto Consulting, Inc. Costs of Developing a Foreign Market for a Small Business: The Market for Non-market Barriers to Exporting by Small Firms. Office of Advocacy, U.S. Small Business Administration (November 2004).

[39] Parsa, t., (2007). why do restaurants fail? part iii: an analysis of macro and micro factors. the dick pope sr. institute for tourism studies, volume iii, pp. 3-16.

[40] Quello, Steve and Graham Toft. "Economic Gardening: Next Generation Applications for a Balanced Portfolio Approach to Economic Growth." The Small Business Economy: A Report to the President. Chapter 6 (December 2006).

[41] Rajaram, R (2008). A Needs Analysis of Financial Management and Accounting Skills in the SME sector in KwaZulu-Natal. Thesis submitted to University of KwaZulu-Natal, Pietermaritzburg(Unpublished).

[42] Raymond M. and Emmanuel M. (2009).Assessing the Institutional Framework for Promoting the Growth of MSEs in Tanzania: The Case of Dares Salaam

[43] Riggs, J. (2007). An Everyday Geography of the Global South. New York: Rutledge MoTI, (1997). Micro and Small Enterprises Development Strategy. Addis Ababa, Ethiopia.

[44] Siva, S, (2012). A Study on Problems Faced by Entrepreneurs of Small Scale Industries. Asian Journal of Research in Social Science and Humanities, 181-188.

[45] Stephen, E., O., and Wasiu, A., B. (2013). The Contribution of Small Scale Industries to The National Economy. Standard Research Journal of Business Management, 1(2), 60- 71.

[46] Tegegne Gebre-Egziabher \& Meheret Ayenew. (2010). Micro and Small Enterprises as Vehicles for Poverty Reduction, Employment Creation and Business Development: The Ethiopian Experience. Forum for Social Studies, Research Report No. 6, Addis Ababa, Ethiopia.

[47] Tylor (2002). Constraints of Growth Oriented Enterprises in the Southern and Eastern African Region; Journal of Development Entrepreneurship Norfolk Vol.7

[48] Uzor, O.O. (2004). Small and Medium Scale Enterprises Cluster Development in Southeastern Region of Nigeria. Institute for World Economics and International Management, pp. 5-15.

[49] Vandenberg, P. (2006). Poverty Reduction through Small Enterprises: Emerging Consensus, Unresolved Issues and ILO Activities. Working Paper No.75.Small Enterprise Development Programmers (SEED), Job Creation and Enterprise Development Department. International Labor Organization (ILO). Geneva, Switzerland.

[50] Werotew, B.A. (2010).Entrepreneurship: An Engine for Sustainable Growth,Development, prosperity and Good Governance, Addis Ababa.

[51] Workneh Fiseha. (2007). The Constraints of Micro and Small Scale Enterprises in Addressing Employment Opportunity: The case of Kolfe Keraneo Sub-city, Addis Ababa. MA Thesis in Regional and Local Development Studies. RLDS, Addis Ababa University.

[52] Yamane Taro (1967). Statistics, an Introductory Analysis, Harper and Row, New York.

[53] Zewde and Associates, Jobs, Gender and Small Enterprises in Africa: Preliminary Report women Entrepreneurs in Ethiopia, 2002.

\section{Web Page}

[54] Garoma, B., (2012). 'determinants of microenterprise success in the urban informal sector of addis ababa. ,Avilable:Zomebo.com/Informal sector, [Online], Available: http://www.iss.nl/ fileadmin / ASSETS/ iss/ Documents/PhD_Abstracts_and_theses/BelayAbstractEng.pdf, [22 jan 2013].

[55] Saleem, M.A. (2011). 'Measuring Impact of Demographic and Environmental Factors on Small Business Performance', Developing Country Studies vol. 1, pp. 37-39,[Online], Available:http://www. Ashen institute. Org// ANDEpercentage20Literaturepercentage20Reviewpercentage20-\%20FIm, [14 Apr 2013].

\section{QUESTIONNAIRES TO FILL BY THE OWNER OF THE BUSINESSES}

This questionnaire is prepared by a graduate student of Adigrat University, College of Business and Economics department of management; for the purpose of donning a study which on titled the 
challenges and opportunities of restaurant and coffee house business in case of Hintalo Wejerat Wereda. This questionnaire meant to secure relevant data to the study, which was believe to come up with valuable recommendations for problems observed (if any). Therefore, your genuine support in responding to the raised questions has paramount importance for the attainment of the study's objectives. Furthermore, the secrecy of all the information that you will provide is confidential. Hence, I earnestly request you to fill the questionnaire carefully. Thank you in advance for your time cooperation.

\section{General Instruction}

$>$ There is no need to write your name

$>$ Close- ended questions answered by placing a tick $(\checkmark)$ mark with in the box.

$>$ The questionnaire will contain $\mathbf{5}$ ( five) parts

$>$ You can select more than one alternative if possible.

Thank you in advance for your kind cooperation and dedicating your time

Sample town

Enumerator's Name

\section{Part 1 Profile of Participants}
1. Sex (owner/manager):
a. Male
b. Female_.

2. Age: A. 18-25 year_.

B. 26-35_ $36-40$

41-45_ above 46

3. Educational Qualification:
a. Uneducated
b. Elementary _
c. Secondary school

d. Diploma

e. Degree

4. What is the form of your business? A proprietorship B partnership

5. Types of business enterprise A restaurant B coffee house

6. The entrepreneur has undergone entrepreneurship training programs Yes

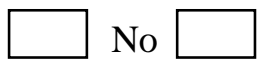

7. Does your business have a business plan? Yes

\section{Part2 The Factors Affecting of Restaurant and Hotels Businesses}

\section{Financial problems}

1. What was your source of finance when you started your business? (more than one answer is possible)

$\begin{array}{ll}\square \text { Own personal saving } & \square \text { nnk loan } \square \text { from the relatives } \\ \square \text { Micro finance institution } & \text { if other specify }\end{array}$

2. What are the challenges in getting loan for the business from finance institution?

\begin{tabular}{|l|l|l|l|l|l|l|l|}
\hline Source of credit & \multicolumn{6}{|l|}{ Challenges faced } \\
\hline Financial institution & $\begin{array}{l}\text { long } \\
\text { process }\end{array}$ & $\begin{array}{l}\text { Collateral } \\
\text { requirement }\end{array}$ & $\begin{array}{l}\text { Bureaucrac } \\
\mathrm{y}\end{array}$ & $\begin{array}{l}\text { High interest } \\
\text { rate }\end{array}$ & $\begin{array}{l}\text { Lack of } \\
\text { awareness }\end{array}$ & $\begin{array}{l}\text { Small loan } \\
\text { size }\end{array}$ & Other \\
\hline Bank & & & & & & & \\
\hline MFI & & & & & & & \\
\hline Personal wealth & & & & & & & \\
\hline
\end{tabular}

Strongly disagree $=5 \quad$ Agree $=4 \quad$ Neutral $=3 \quad$ Disagree $=2 \quad$ strongly Agree $=1$

\begin{tabular}{|c|c|c|c|c|c|c|}
\hline No & Variables & 5 & 4 & 3 & 2 & 1 \\
\hline 3 & There isenough current capital to run the business & & & & & \\
\hline 4. & The firm suffers with bad debts & & & & & \\
\hline 5 & Shortage of credit & & & & & \\
\hline
\end{tabular}


Factors Affecting of Small-Scale Enterprise (Restaurant and Hotels) Inraya Azebo Wereda: The Case of Mohoni, Maychew and Korem

\section{Marketing Problems}

Very high $=5 \quad$ high $=4 \quad$ Neutral $=3 \quad$ Low $=2 \quad$ no effect $=1$

1. Indicate the degree to which the markets distress the performance of your business

\begin{tabular}{|c|c|c|c|c|c|c|}
\hline No & Variables & 5 & 4 & 3 & 2 & 1 \\
\hline 6 & Lack of skill to set comparatives price & & & & & \\
\hline 7 & Lack of demand forecasting & & & & & \\
\hline 8 & Poor customer handling and relation ship & & & & & \\
\hline 9 & Inability to modify existing product & & & & & \\
\hline 10 & Inability to promote the product & & & & & \\
\hline 11 & $\begin{array}{l}\text { The products of the firm are designed based on the customer } \\
\text { expectations }\end{array}$ & & & & & \\
\hline
\end{tabular}

12. Do you think your business area is in the right market location? Yes

\section{Legal and Managerial Problems}

Strongly disagree $=5 \quad$ Agree $=4 \quad$ Neutral $=3 \quad$ Disagree $=2 \quad$ Strongly Agree $=1$

\begin{tabular}{|l|l|l|l|l|l|l|}
\hline No & Variables & $\mathbf{5}$ & $\mathbf{4}$ & $\mathbf{3}$ & $\mathbf{2}$ & $\mathbf{1}$ \\
\hline $\mathbf{1 3}$ & Implementation of rule and regulation & & & & & \\
\hline $\mathbf{1 4}$ & High tax rate & & & & & \\
\hline $\mathbf{1 5}$ & Managerial problem & & & & & \\
\hline $\mathbf{1 6}$ & Let to give licensing & & & & & \\
\hline
\end{tabular}

17 Do you think the tax collectors are fair? Yes

18. If the tax collectors are not fair, what the problem did you observe?

19. To what the extent your business successes depend on the support provider SMEs office.

Very high $\square$ high $\square$ medium $\square$ low $\square$ very low

20. what do you examine the contrbution office of SMEs in solving challengs of the business?

There is good improvement $\square$ there is no change $\square$ decrease

Problems of Infrastructure

Very high $=5 \quad$ high $=4 \quad$ Neutral $=3 \quad$ Low $=2 \quad$ very low $=1$

How do you assess the access and quality of the following infrastructures for your business?

\begin{tabular}{|c|c|c|c|c|c|c|}
\hline \multirow[t]{2}{*}{ NO } & \multirow[t]{2}{*}{ Variables } & \multicolumn{5}{|c|}{ Quality } \\
\hline & & 5 & 4 & 3 & 2 & 1 \\
\hline 21 & Electricity & & & & & \\
\hline 22 & Water & & & & & \\
\hline 23 & Telephone & & & & & \\
\hline 24 & Transport & & & & & \\
\hline
\end{tabular}

\section{Problems of Competitors}

Strongly disagree $=5 \quad$ Agree $=4 \quad$ Neutral $=3 \quad$ Disagree $=2 \quad$ Strongly Agree $=1$

\begin{tabular}{|c|c|c|c|c|c|c|}
\hline No & Variables & 5 & 4 & 3 & 2 & 1 \\
\hline 25 & There is high level of competition from the compotators & & & & & \\
\hline 26 & The able to sustain competition enterprise & & & & & \\
\hline 27 & $\begin{array}{l}\text { The enterprise is able to afford production at reasonable price so, that it can } \\
\text { with stand }\end{array}$ & & & & & \\
\hline 28 & The enterprise have regular customer and the traffic is good enough profit & & & & & \\
\hline
\end{tabular}


Factors Affecting the performance of Small-Scale Enterprise (Restaurant and Hotels) Inraya Azebo Wereda: The Case of Mohoni, Maychew and Korem

\section{Operation Problems of Restaurant and Hotels Business}

\begin{tabular}{|c|c|c|c|c|c|c|}
\hline No & Variables & 5 & 4 & 3 & 2 & 1 \\
\hline 29 & $\begin{array}{l}\text { The business provide variety of products/service to cater the needs of all types of } \\
\text { customers }\end{array}$ & & & & & \\
\hline 30 & $\begin{array}{l}\text { The business has enough space to accommodate the fluctuations in customers' } \\
\text { arrival }\end{array}$ & & & & & \\
\hline 31 & $\begin{array}{l}\text { The business has enough service facilities in meeting out the fluctuations in the } \\
\text { number of customers }\end{array}$ & & & & & \\
\hline 32 & $\begin{array}{l}\text { The business has enough utensils to meet out the fluctuations in customers' } \\
\text { arrival }\end{array}$ & & & & & \\
\hline 33 & $\begin{array}{l}\text { Because of lack of additional facilities in the restaurant and coffee house such as } \\
\text { television etc. the restaurant and coffee house losses or unable to withhold the } \\
\text { existing customers }\end{array}$ & & & & & \\
\hline 34 & $\begin{array}{l}\text { How do you see the ambience (atmospheric conditions) of the restaurant and } \\
\text { coffee house are attractive and itself promoting customers }\end{array}$ & & & & & \\
\hline
\end{tabular}

\begin{tabular}{|c|c|c|c|c|c|c|}
\hline No & Variables & 5 & 4 & 3 & 2 & 1 \\
\hline 35 & There is lack of power availability reason for production/ service interruptions & & & & & \\
\hline 36 & There is Lack of manpower reason for production/ service interruptions & & & & & \\
\hline 37 & There is Lack of skilled manpower reason for production/ service interruptions & & & & & \\
\hline 38 & The business is not facing problems with regard to availability of materials & & & & & \\
\hline
\end{tabular}

Citation: Meseret Meresa. "Factors Affecting the performance of Small-Scale Enterprise (Restaurant and Hotels) Inraya Azebo Wereda: The Case of Mohoni, Maychew and Korem" International Journal of Managerial Studies and Research (IJMSR), vol 6, no. 1, 2018, pp. 68-92. doi:http://dx.doi.org/10.20431/23490349.0601010 .

Copyright: () 2018 Authors. This is an open-access article distributed under the terms of the Creative Commons Attribution License, which permits unrestricted use, distribution, and reproduction in any medium, 